\title{
3 The rights of trees: on a Hungarian short story \\ 4 from 1900
}

5 Péter Hajdu ${ }^{1,2}$

8 Abstract This paper analyses a short story written in 1900 by Kálmán Mikszáth 9 (1847-1910), a major Hungarian author. The plot narrates the genesis and the 10 consequences of a strange last will, which bequeaths a substantial amount of money 11 to two trees. The plot is partly funny, partly uncanny, and evolves rather slowly, in 12 accordance with the long and rather inactive life cycles of trees. It is not so much the 13 plot, however, that is interesting, but rather the ethical discourse of the personae in 14 how to deal with the trees. Due to the exceptional legal situation, various people 15 start regarding the trees as persons and have difficulties in making decisions about 16 them. While it would be an overstatement to say that Mikszáth wrote a prototext of 17 environmental justice, he definitely challenged some ideas of his times and asked 18 important questions about possible ethical approaches to nature. Legal issues are 19 ubiquitous in world literature, but the world of law is usually limited to human 20 affairs. As soon as trees are treated as legal subjects, they seem to become persons. 21 Usually the development is the reverse in legal reasoning: if one is a person, one has 22 rights. Therefore the short story is a sort of thought-experiment: what if we regard 23 the non-human world as having rights? And the result is a paradigm shift we can 24 nowadays make use of, accepting that justice is not or should not be limited to just 25 the human sphere.

Keywords Environmental rights · Short story analysis · Kálmán Mikszáth · Stories about trees

A1 $\square$ Péter Hajdu

A2 hajdu.peter@btk.mta.hu

A3 1 Research Center of Humanities, Hungarian Academy of Sciences, Budapest, Hungary

A4 2 Shanghai Jiao Tong University, Shanghai, China

Springer

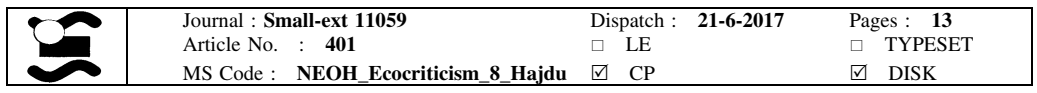


In "Two Trees," the first poem of his collection of poetry entitled Rain, Don Paterson (2009) tells a story of an orange tree and a lemon tree grafted together then separated. In the second stanza, a negative description tells what the trees do not do to mourn their separation, because "They were trees, and trees don't weep or ache or shout. / And trees are all this poem is about." The very act of denying that the poem has another topic than trees makes a reader think about such possibilities, which may make the poem a fable or a parable, or at least an extended metaphor of relationships and separations. As if the narrator ironically said: "And don't think that I was speaking about my terrible break up." However, a critic trained in ecocriticism can hardly resist the temptation to read the closure literally, which makes the poem a meta-poetic discourse on the impossibility of giving voice to creatures that literally have no voice to speak for their rights. Even a poem exclusively on trees tells about what humans do for the trees, and what trees do not do, in a very anthropomorphic language. And even the declaration that the poem is about trees makes it a poem about human beings. But a poem about why I cannot write a poem about trees is already a poem about trees, isn't it?

This vicious circle may characterise the short story I am about to analyse here, too. No reader can be really sure if it is about human characters or trees. However, the experience of ecocriticism makes us tend to focus on the issues of the non-human actants in a retrospective reinterpretation of the text. Kálmán Mikszáth (1847-1910), the author, is nowadays regarded as having an in-between position, since around 1900 he partly continued nineteenth-century narrative methods, but partly initiated modernism. When in 1910 the whole country celebrated the 40th anniversary of his debut as a writer, all the conservative literary circles made their tributes, while representatives of the (at that time more or less new born) modernist movement emphasised that he was a great author whose greatness the conservatives would never understand. Since we usually can find ideas and attitudes in Mikszáth's writing that became very important in western literature only later, sometimes much later, it seems interesting to scrutinize his ethical attitude towards nature, even if we can never dare to call him a nature-writer. On the one hand, he usually leaves ethical judgement suspended at the end. Relativism can describe both his epistemological attitude, but also his ethical standpoint, which however does not imply an "anything goes" approach, but a wise distance suggesting that one should not waste the energy of extreme indignation on more or less tolerable issues. ${ }^{1}$ On the other, he wrote a handful of short stories on animals (mostly domesticated ones in a human environment), but only once did he go so far as to write about trees. That short story, called "The Compossessor Trees" or "The Land-Owner Trees," was published in 1900 in a literary magazine and in 1901 in a short story collection as the opening piece (Mikszáth 1900, 1901).

What kind of short story can have a plot that starts in 1736 and ends in the 1860s? A modern short story is supposed to have a condensed plot, representing only one single event from the life of the protagonist, which should be the turning point of his or her fate. ${ }^{2} 130$ years seem a bit too much for that. The first and easiest answer

${ }^{1}$ On such issues see my book, Hajdu (2012).

2FL01 ${ }^{2}$ This is a simplified summary of the huge academic discourse on the genre 'short story'. Instead of 2FL02 quoting many papers or one with an exact formulation I like, I refer to a pioneering and a summarizing work, respectively: O'Connor (1953) and Pratt (1981).

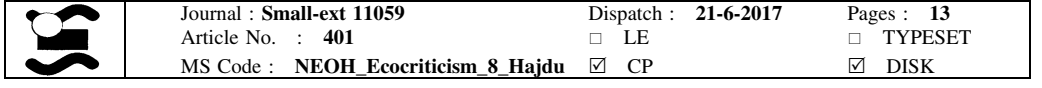


could be that it is not a modern short story, but an old fashioned tale with slow and uneconomical narration. The second answer is that the 130 years' time span is only the consequence of its tripartite time structure with its backstory, main story and epilogue. The whole work occupies 31 pages in the first book edition. ${ }^{3}$ The pre-story is narrated in six pages: Pál Lányi plants the two trees; about 40 years later, Queen Maria Theresa visits them, and Pál Lányi dies leaving a will that bequeaths a substantial amount of money for the trees to be taken care of. The main story starts another 40 years later, and takes 23 pages. Károly Lányi, a young gentleman, badly needs the money of the trees for his marriage plans. After one of the trees dies naturally, he eventually makes up his mind to cut down the other. However, when he is leaving the forest a branch of a tree knocks his eye out. In the two-page-long epilogue the previously omniscient narrator turns suddenly personal and tells us how he, as a young boy, met the old Károly Lányi as a relatively poor man, probably in the 1860s. And even in the main story there is a fourteen-page-long narration of a single night that has a decisive effect on the protagonist Károly Lányi's life. Even if the series of circumstances that made that single event possible may seem a bit long, the work can fit the definition of the modern short story, since the epilogue only proves that the main event was indeed decisive.

There is, however, a third possible answer, namely that a short story in which the protagonists are trees must work with a bigger time-span, since it cannot make use of the condensing techniques of stories on humans. Explaining the first two ideas about the possible ways to cope with the peculiarities of this short story, I regarded it as self-evident-in accordance with the entire corpus of short story theory and analysis - that a short story must tell us something about human life. But let us test this presupposition. Not only the title displays the trees as protagonists, but the narrator also declares something like that at the very beginning: "Our story is about two enormously grown up lime trees" (130). I have to admit that it is only a small proportion of the text in which the trees do tree things, like when they grow, become green in springtime and drop their leaves in fall, when they rustle, or bloom. There are some sentences that narrate how they do tree things, mostly very poetic sentences, but the narrative does not focus on their lives as trees, rather on their position in human society. We cannot speak of their interactions with humans, since the trees are mostly very passive (which is hardly a surprise). What makes a story here is the changes of human relationships with, and human evaluations of the trees. The main question, however, is their life, or rather their right to life.

The question arises whether the ethical question about the rights of two particular trees can be generalized as being about environmental justice or the rights of nature. The question is obviously provoked by our twenty-first-century perspective, but there are some hints of the legitimacy of a generalizing approach in the short story too. Not about the rights of trees in general: nobody in the represented world thinks that cutting down any tree is problematic. "What is a tree?" asks Károly Lányi's mother rhetorically (136), implying that a tree is nothing of any significance. Károly tries to calm down, telling himself that trees "are not living creatures." (138)

\footnotetext{
${ }^{3}$ The proportions of the story can be best shown in the first book edition (Mikszáth 1901). Later I will
} refer to the critical edition (Mikszáth 1915) in my own translation, putting the page numbers in brackets. 
115 However, the narratorial discourse seems to undermine the anthropocentric attitude 116 when it puts humans on the same level as other beings: "About forty years passed 117 over this old globe of mud, where there is so much grass, so many trees, so many 118 men, and so many bugs." (132) When the human protagonist tries to cut down a tree 119 he feels shame because the stars are looking at him (141), which either means that 120 for the ethical evaluation of an action all the beings of the universe, even the stars 121 and therefore everything, should be taken into account, or that there is a higher, 122 transcendental viewpoint from which killing a tree is a sin.

What makes these two protagonist trees so special? Cutting down trees was an everyday occurrence in the period when Mikszáth wrote this short story, even if the speed of the current deforestation was unimaginable. Some trees are protected by law nowadays, either because they are rare species and as such they are parts of the natural heritage, or because they are standing either in an urban environment or in a national park. Such protection did not exist that time. Károly Lányi kills a tree, and then thinks that all the trees in the world want to take revenge on him, but it does not occur to him that they might also seek revenge for the tree of which the coach was made that he is using to go there, or the handle of the axe he used to commit the deed. But these two particular trees are regarded as individuals by more and more people in the represented world. The first and for a long time the only person to do so is Pál Lányi, who had planted them, and in his old age started to think that this was the only really valuable achievement of his life. He is the first to treat the trees (but only these two trees) as persons: "He usually talked with them as if with some intelligent beings." (130) And he leaves a sum of money for them, giving them a legal existence and a place in human society. Before that, however, there is another important turn of events when Queen Maria Theresa gives the trees proper names. To be precise, the Queen only asks her chancellor Kaunitz to carve her initials in the trees, but the local community interprets this as a kind of baptism: "This was the way the tree with " $M$ " became Maria, and the other one with " $T$ " Theresa." (131) Whoever has a name is already almost a person. One spring, when Theresa is late spreading her leaves, the guardian tells her: "What the hell, Tess? Are you crazy, Tess? Don't mess around, Tess! Hurry up, Tess!" (135) He also speaks to the trees and calls them by their names.

The fact that both trees are given female names may solicit associations with ancient Greek mythology where trees have a female principle, and every tree has a hamadryad, a forest nymph that is born and will die with it (or rather her). The individual status and the female essence of the trees are expressed together when some wandering students sigh: "It would be so great to marry one of them!" (133) But the final step of their social acceptance, I think, happens when the young Károly Lányi paints a picture of the two lime trees, which was "hung in the big dining room among the other family portraits." $(134)^{4}$ With this gesture, the Lanyis declare the trees to be members of the family: they are not the favourite trees of a late uncle any 156 more, but rich relatives, whose heritage one can look forward to. When Theresa dies 157 of desiccation, the declaration of the local court also refers to them as persons: "The surviving tree inherits the goods of the deceased." (135) Not only is the vocabulary

4 Italics mine.

\begin{tabular}{|l|lllll|}
\hline & Journal : Small-ext 11059 & Dispatch : $\mathbf{2 1 - 6 - 2 0 1 7}$ & Pages : 13 \\
& Article No. $: 401$ & $\square$ & LE & $\square$ & TYPESET \\
& MS Code : NEOH_Ecocriticism_8_Hajdu & $\nabla$ & CP & $\square$ & DISK \\
\hline
\end{tabular}


definitely human, but it is also important that the surviving tree has unconditional capacity to inherit. The tree once became an heir due to a sentimental old man's caprice and the approval of an old queen who was personally involved, but it is declared now that this was not a one-off event, since Maria can inherit again and again. The local court does not offer any explanation (or the narrator does not share it), but it is rather obvious that the trees are generally accepted as family members, and are the closest relatives of each other in the family network, to avoid the expression "family tree" here. From the creation of the eccentric will, more and more people come to regard the trees as persons, until Károly Lányi's mother declares that they do not have full rights. She suggests a very simple solution to her sons financial problems: he should cut down the tree to get the inheritance, which would be neither a crime nor unethical; as she puts it, it is "nothing terrible." Carrying out the plan, however, is not simple. Károly Lányi must act secretly by night, because public opinion in the local community would probably be critical of the act. His helper, Toportyán, thinks that they will be in trouble if they are caught by shepherds woken by the sound of the falling tree. The Lányi clan supposes that the locals would react violently in retaliation. But can be there any legal consequences? Normally we do not have the right to cut down a tree that belongs to someone else. And a tree always belongs to an owner, more exactly, to the owner of the land it is standing on. A tree is part of a property. In the fictitious world of this short story, however, the trees themselves own the land they are standing on, therefore there is no human owner whose rights would be violated when they are cut down.

We can suppose that technically Pál Lányi must have created a foundation the only purpose of which is to take care of the trees, therefore they would not really become legal entities, inheritors, or land owners. ${ }^{5}$ Such a simple legal affair would not need royal confirmation. However, in the story the will, regarded as blatantly eccentric, is not valid until the Queen personally endorses it. The legal formulation, the actual solution of fulfilling the testator's intention does not seem to have any importance: both the text of the will quoted in the short story and the human community take the lime trees themselves to be the heirs. According to the will the trees are not part of the meadow, but they own it, just as the title of the story calls them possessors. Therefore there is no owner, no human agent whose rights would be harmed by the act of cutting down that tree.

The will commissions a committee to appoint a guardian for the trees. This person, however, is sometimes referred to in the short story as tutor. The difference is that adults have guardians, minors have tutors. A contemporary lexicon described the kinds of adult persons that can (or should) be under guardianship as follows:

\footnotetext{
5 Vilmos Kráhl, who wrote a complete book on the legal themes in Mikszáth's writing, summarises the situation as follows: "Testator Pál Lányi leaves 85 acres of land and 4000 thalers for a fund, the purpose of which is to take care of two memorial trees and to cover the costs of the legal apparatus necessary for that. The fund does not have any ideological purpose, and the testament does not contain any other legacy." Although the word "fund" cannot be found in the short story, Kráhl takes it for granted that this technique was applied. (Kráhl 1941, 116)
} 
1. when someone is unable to handle his or her fortune due to their physical or mental deficiencies,

2. the profligate,

3. those who have been absent in unknown locations for at least one year,

4. those sentenced to prison or jail. ${ }^{6}$

Since eighty-year-old trees can hardly be minors, we should suppose that they have guardians because of their physical deficiencies, even if it might be politically incorrect to call a deficiency that a tree cannot move or speak. It may seem that being under guardianship mean restrictions of someone's rights, and this is obviously true in the case of profligate persons: they are not allowed to do with their fortune what they want. Indeed this institution serves to guarantee the advocacy of those people who for some reason are unable to represent themselves. If the trees are under guardianship, it means that they are not persons of full ability of action, but this does not deny their rights. They need someone to handle their money, but they have the right of possession and the right to inherit. The third basic right contemporary law guaranteed for those under guardianship is that of marriage. It is possible that the trees also have that right. ${ }^{7}$

Mrs. Lányi, however, points out sharply that even if those trees have been provided with the legal ability to inherit as persons, the laws that protect human life will not be applied to them. Cutting down the tree is certainly not murder. However, the text creates some doubts or ambiguities around this certainty. Only in a simile, but Mrs. Lányi herself speaks of "killing the testator" and the unnatural death of the lime tree. (136) When Károly Lányi makes up his mind, he thinks: "I will kill the tree." (137) Toportyán tries to encourage him, saying he should not behave as if they were going "to commit an outrageous crime," "to commit murder." (140) Toportyán explicitly denies that what they are doing is murder, but the narrator when they are already using their saw says of the tree: "It did not know anything about being murdered." (Ibid.) Metaphors, explicit denials and a narratorial declaration contribute to the plausible constitution of a possible ethical position, according to which cutting down a tree is murder.

Or should we speak about environmental destruction? This was obviously not a concern in 1900, although it concerns people less even today than it should. However, the concept can influence the interpretation of a reader today. But destroying the environment is not something that usually has legal consequences. To mention only one example, the Baia Mare cyanide spill wiped out the complete fish population of a $965 \mathrm{~km}$ long river, but through the creative liquidation of the mining company responsible, its owners managed to get away without paying a cent in compensation or fines. Environmental destruction can be regarded as rather an ethical than a legal issue from the viewpoint of readers today.

${ }^{6}$ Pallas 1893-1897, "Gondnokság."

${ }^{7}$ As we saw, some students express the wish to marry one of them, but the story does not really consider this possibility. We know that they have the right to inherit because a situation in the plot raises this problem. We do not know what the guardian would have decided if a youth from a good family, prompted by sincere emotions, seriously proposed to one of the trees.

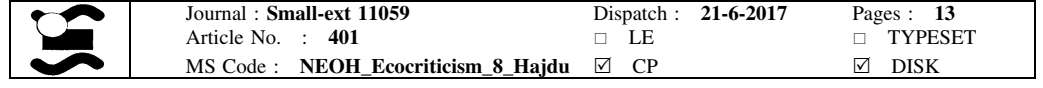


Another ethical issue is the intention of the testator. In the case of literary texts we have long stopped talking about the intention of the author, but it is a vivid practice with legal texts. Like every text, a legal text needs interpretation. A text exists through reading, interpretation and application, and the application of a generally formulized law to a concrete case cannot be self-explanatory. In the hermeneutics of legal texts the intention of the author must be actualized. The legislator wanted a reaction to a category of cases; it is open to debate whether the given case belongs to that category, and if so, how one should practically decide, but all this has the function of fulfilling the legislator's intention. It is even more true about a final will. The testator's intention can be taken into consideration as far as it can be understood from the text of the will (and if it does not contradict the general regulations). Pál Lányi's intention is quite clear: he ordered the legacy because he wanted his lime trees to live safely as long as possible. When Károly Lányi cuts down the tree, he does the exact opposite of the testator's intention and he knows it. We should also note that the guardian's actions do not harmonise with the will's intentions either. The testator suggested that a permanent guard should be hired to protect the trees. If there had been such a guard, Károly could not have cut down the surviving tree. Some fine hints in the text imply that the fund is not handled trustfully. ${ }^{8}$ The main goal of the foundation, the protection of the trees is not fulfilled.

Nobody seems to care about the testator's intention, until Károly comes to believe he is intervening personally. Pál Lányi's grave is under the lime trees, and it caves in under Károly's foot, leading him to believe this is a manifestation of transcendental disapproval. At this point even his intrepid helper, Toportyán sees fit to deliver a speech to convince the deceased testator that his real intention will be fulfilled. According to Toportyán the testator wanted to take care both of his brother's family and the trees, but rather of the family, since he left much more to them. In the present situation, however, "one of them must perish," and it is quite acceptable that it should be the tree (142). However, to perish means two quite different things for the man and the tree. For the tree, to stop living; for the youth, some diminishment of his social status. Károly Lányi ultimately fails to realise his planned wedding, therefore the closure of the short story shows us the misfortune that could have happened to him. He becomes a county scribe in threadbare clothing. At the end he does not belong among the wealthy anymore and has lost the family house and the estate. He lives in modest circumstances, but not in deep poverty. It is possible that he was hired for a clerical job due to his family connections, ${ }^{9}$ but he is said to have "beautiful handwriting" (145), therefore it is also possible that he can make a living because of his personal achievement. The diminished prestige and the fact that he failed to "save the name and the house of the Lányis" (136) must be painful, but that is all "perishing" means for him.

8 "The two lime trees were quietly enjoying their income-at least the fraction the guardian gave them" (132-133). It is the district administrator's responsibility to appoint the guardian, and the fact that he appoints his own brother-in-law suggests some corrupt machination (134).

9 After 1867 the middle gentry, unable to keep up with the competition of the capitalist economy, monopolised the state administration in Hungary.

\begin{tabular}{|l|llll|}
\hline & Journal : Small-ext 11059 & Dispatch : $\mathbf{2 1 - 6 - 2 0 1 7}$ & Pages : 13 \\
Article No. : 401 & $\square$ LE & $\square$ & TYPESET \\
& MS Code : NEOH_Ecocriticism_8_Hajdu & $\square$ CP & $\square$ & DISK \\
\hline
\end{tabular}


However, the supposed intervention of the deceased great uncle is only the first of a series of hints that there is a wider context than human society to interpret Károly's deed, and there are other beings who may have an opinion about it. The moon looks down "as if to say 'I see you'." (142) But first and foremost it is the other trees that Károly regards as hostile, judgemental, vengeful entities. And when the branch of a tree hits his eye during his escape, it can easily be interpreted as the vengeance of the trees.

The inheritance from the tree, however, would not have stabilised his financial situation permanently. He was planning to marry a wealthy bourgeois girl-the usual career strategy of good-looking but financially uncertain young gentry in literature-but he needed the money to be able to court her properly. Losing his eye ruins his chances for a good marriage. There is a rational explanation for the accident: they were going too fast with their coach, the branch caught in the shaft of the cart, so it hit "his face with incredible force." (144) Right in his face, right in his eye. A fatal coincidence? He does not think so. Aristotle wrote in his Poetics: "in that way incidents will cause more amazement than if they happened mechanically and accidentally, since the most amazing accidental occurrences are those which seem to have been providential, for instance when the statue of Mitys at Argos killed the man who caused Mitys's death by falling on him at a festival. Such events do not seem to be mere accidents. So such plots as these must necessarily be the best." (Aristotle 1927, 1452a6-10) The modes of representation are, of course, different. We may say that the statue represents the model metaphorically, while a tree another tree or the whole species metonymically or as synecdoche. But it is easy to see the same kind of (magical?) thinking here, from the perspective of Aristotle and Károly Lányi, namely that "such events do not seem to be mere accidents."

This may recall Tzvetan Todorov's description of the fantastic: the protagonist is unable to communicate his supernatural experience, since all the phenomena that anybody can experience have a rational explanation, and there is no proof that what only he experiences also exists outside his psyche. He cannot easily convince himself that his own experience is real (Todorov 1975). ${ }^{10}$ Mikszáth's short story is not fantastic, because it is not focalised from the protagonist's viewpoint exclusively, but it still has the potential of the fantastic, because Károly Lányi's interpretation of the events, derided and rejected by everybody else, does not lack meaningful coherence. The world in which he has to live after losing an eye is absurd and horrific. He thinks that all trees are his personal enemies and he does not dare to go near them, which makes his life difficult even in an urban environment. ${ }^{11}$ This unexpected threat from harmless creatures may remind us of the revolt of birds. ${ }^{12}$ Due to his strange ideas he is the butt of inexhaustible ridicule for the town kids, who summarise the obvious explanation in the final sentence of the short story

10 A definition-like formulation: "The fantastic is that hesitation experienced by a person who knows only the laws of nature, confronting an apparently supernatural event." (Todorov 1975, 25)

${ }^{11}$ His personal horror story, even if it is ridiculed by many other actants of the story, can evoke the notions of botanophobia and ecophobia too. See for example Wald (2013) and Estok (2016), respectively.

12 For the literary predecessors and sources of Hitchcock's The Birds see Mogg (2009).

\begin{tabular}{|l|llll|}
\hline & Journal : Small-ext 11059 & Dispatch : & $\mathbf{2 1 - 6 - 2 0 1 7}$ & Pages : 13 \\
& Article No. : 401 & $\square$ LE & $\square$ TYPESET \\
MS Code : NEOH_Ecocriticism_8_Hajdu & $\square$ CP & $\square$ & DISK \\
\hline
\end{tabular}


as follows: "Because he is crazy." (146) This suggests that the second, fantastic, story has only a psychological reality.

Károly Lányi also seems to have a tainted heredity. The narrator speaks about the "sick love" of Pál Lányi towards his lime trees (131). ${ }^{13}$ György Lányi was "obsessed" with the family tree. ${ }^{14}$ (133) It is interesting that not only do the trees become family members, but the family also becomes a tree, at least in György Lányi's obsession. Of his son the narrator says: "Mr. Joseph Lányi had a 'tainted heredity' as doctors usually put it." He is manic about lawsuits (133) After cutting down the tree, "the light of madness" glimmers in Károly's eyes (143), and Toportyán fears "he has lost his mind" (ibid.). During his sickness the doctors think that "he will hardly become normal again." (145) However, the short story is much more complex than a simple report of the strange relationship the more or less crazy members of an eccentric family develop towards two trees. It is true, though, that normal, human society does explain their behaviour this way.

Károly Lányi was a bit strange even before the night in the woods made him sick and mutilated. He is introduced to the reader as follows:

He had pale, spleeny face; no young girl can resist that. In addition he had a slim, fragile figure. In general he was a very interesting youth; sensitive, moony, "half a painter", as they called him. His big eyes were shining with some peculiar, other-worldly light. (14-15)

$\mathrm{He}$ is called "half a painter" not only because he could paint a little, but also because society regarded him as a kind of artist, or rather an almost-artist. He is attractive, but not due to vital masculine energy, but to his vulnerability and otherworldly nature. Spleen, paleness, fragility, sadness make him attractive to young girls-maybe only to very young ones. Two interpretative paths fork here.

The first possibility is that Károly Lányi's weak, vulnerable constitution cannot bear the night in the woods, therefore he becomes sick and mad. He assigns importance to phenomena he should not, because his eccentric fantasy does not allow him to experience reality as it is. Human society seems to interpret his story this way; such ideas and viewpoints appear in the utterances of his mother, his servant Toportyán, and especially the merciless town kids. This interpretation is never completely explained and coherent, nor does it dominate the world of the short story. The narrator does not endorse it.

The second possibility is that his sensibility allows Károly to experience things hidden to the eyes of average people. This would be similar to the tradition of the Künstlerroman in the 19th and 20th centuries. As half an artist he does not have the fate of an artist, although his experience is in a way artistic. He is the only one who understands the total ethical dimension of the tree's destruction, from a universal or

13 Todorov thought that the main function of fantastic literature was to create an opportunity for coded discourse about topics modern literature already has the liberty to speak explicitly. What stories of vampires and the living dead really are about is necrophilia. The expression "sick love" was probably much less associated with sexual perversions in 1900 than today. However, we should remember that there are people in the story who wish to marry the trees. Dendrophilia can be a leitmotiv of the short story, and we can see a development from dendrophilia to dendrophobia in the discourse.

14 In italics in the original too.

Springer

\begin{tabular}{lllll} 
Journal : Small-ext 11059 & Dispatch : & 21-6-2017 & \multicolumn{2}{l}{ Pages : 13 } \\
Article No. $\quad: \quad \mathbf{4 0 1}$ & $\square$ & LE & & $\square$ \\
MS Code : & NEOH_Ecocriticism_8_Hajdu & $\square$ & CP & $\square$ TYSET \\
\hline
\end{tabular}


pantheistic viewpoint. When he spends the night alone in the woods, he experiences the universal sublime and the numinosity of nature. The first sentence describing the forest says: "It was a pleasant May evening; the forest exhaled balm; thousands and thousands of living creatures were vibrating in it." (137) The forest, however, is not only pleasant and balmy with its vibrations: "Silence came, the solemn silence of the forest. Now and then a cool breeze blew among the trees; a billion branches rustled together, strangely, mysteriously. A horrible cold ran down his spine." (138) The adjectives solemn-mysterious-horrible imply the sublime and numinous character of nature, and the numinous is also terrible and frightening. ${ }^{15}$ Károly thinks that the mighty world of vegetal nature is hostile towards him, and he finds reassuring even the thought that he is afraid of some robbers. But the forest has something to answer to that thought:

An easy wind passed over the trees now, making the mass of foliage buzz and move like a camp. From this dull buzz as if an admirable, reasonable voice shot out:

"It is not the robbers you fear, Lányi, Lányi, Lányi!"

And a thousand trees nodded assent with their heads.

Woe! He really felt that it was not the robbers he feared, he rather wished one would come and shout at him so that a human voice would break the uncanny, frightening whisper of the forest.

Nothing is more horrible than this.

It is a very old tradition that a man alone in nature may experience the transcendental and hear voices in the woods. In the Roman religion, Faunus was the god of voices to be heard in nature. ${ }^{16}$ Károly will see his figure a little bit later (actually several of them, because his Hellenised version was identified with satyrs, therefore there could be more than one of him). Since what he sees in the woods is very similar to the general human experience of the transcendental, the short story offers the possibility to interpret the narrative in this way: the highly sensitive almost-artist understands the real mechanisms of sublime nature, thus only he can feel the universal ethical burden of his sin against the vegetal world. In this interpretation he is a tragic hero who has obeyed the pressure of human society, and applied his behaviour to a lower value system, only to experience a double punishment: on the one hand, he has to understand what his deed really means, on the other hand, with his eye he loses any opportunity of financial success. As an old man he becomes utterly misanthropic, due to his relationship to other non-human beings, his dogs. The boys of the town's secondary school love to throw stones at them, and he has frequent quarrels with them to protect his dogs (the boys can always take refuge under the trees). His love towards his dogs is not interpreted in the story in any way; it is only said that he hates the children because of his dogs. However, we can suppose that a person who understands his behaviour as ethically judged in a universal context, in which all the living and non-living, human and

15 Otto $(1917,5-7)$.

16 "Man schrieb ihm die mannigfachen, oft unheimlichen Stimmen und Naturlaute zu." (Roscher 18861890, vol. 1, c. 1456).

\begin{tabular}{|l|lllll|}
\hline & Journal : Small-ext 11059 & Dispatch : 21-6-2017 & Pages : 13 \\
Article No. : 401 & $\square$ LE & $\square$ & TYPESET \\
& MS Code : NEOH_Ecocriticism_8_Hajdu & $\square$ & CP & $\square$ & DISK \\
\hline
\end{tabular}


non-human entities matter, develops an antagonistic relation to humanity because he experiences a generally hostile attitude towards non-humans, which includes his own act against a tree that he deeply regrets.

The short story as a whole, however, is not tragic. The tragic quality is only one of the options it offers. The narrator is extremely low-key in interpretative utterances. He only sketches a few psychic or other developments, leaving the task of a coherent interpretation to the reader, although he implies contradictory narratives that mutually exclude each other. From the viewpoint of cultural history, one of these is closer to Romanticism, the other to modernism. The Romantic one is the story of the almost-artist, who is alone able to see the marvellous in the world, trembling in the moonlit night when a grave caves in, riding through a forest full of monsters. The story is Romantic not only because of these features, but also because experiencing the marvellous in a dreary, normal world is the key problem of Romanticism (Pikulik 1979, 322-340). According to another narrative, Károly Lányi is a sickly, infantile youth, and it is his own weakness that makes him lose his mental balance. This story may be called modernist because it offers a purely psychological explanation and sees the events basically happen inside the human mind. Some of the monsters Károly Lányi sees in the woods are really infantile, like his own schoolteacher, a stall-keeper and a hangman he saw as a boy (143). This childish nature of his night visions, deeply anchored in his personal memories, nevertheless provokes psychoanalytic interpretation.

It is already the result of Kálmán Mikszáth's characteristic narrative technique that the two stories seem equally valid, and the narrator takes a position equally alienated from both. In fact, both appear in an ironic or even parodistic way. Some of Lányi's nightmares, like the giant goat running on one leg, the bear sticking out its tongue, or the old teacher threatening with a cane, seem to parody both Romantic revelation and psychoanalysis. ${ }^{17}$ Moreover, the short story seems to have an ironic relationship to narration too. In the epilogue the narrator suddenly becomes homodiegetic and starts speaking of how he as a schoolboy saw Károly Lányi as an old scribe, undermining his authority and the reliability of his own narrative voice. Up to this point the narrator has seemed heterodiegetic and omniscient. He has related a dialogue that happened in the imperial chambers of Vienna between Maria Theresa and Kaunitz, and also the silent thoughts of the protagonist while alone in the middle of the forest. When this narratorial voice is attached to a "real" person, all the previously transmitted knowledge, legitimised only by the narrator's position, loses its absolute epistemic status.

17FL01

17 It goes without saying that it would be slightly anachronistic to suppose the intention of parodying psychoanalysis on behalf of the author in 1900, the very year when Freud's Traumdeutung was first published (even if the story was written in December, and Freud's book was actually published on 4th November, 1899, more than a year earlier). Nevertheless, the text can provoke such a reading after Freud. And we should not forget that the literature in Freud's time and geographical region offered many interpretations of human behaviour that Freud himself found similar to his approach. The most notable case is that of Arthur Schnitzler. Mikszáth's short story may parody a way of thinking that in the same year resulted in the founding text of psychoanalysis. 
Whichever narrative readers choose (and especially if they make both interact), the rights of the trees pose the central ethical question. The century-long story is not very exciting from the viewpoint of the lime trees, since acquiring fame and wealth, or attracting love and envy are obviously not their concern. The narrative tends to emphasise their disinterest and calmness. Even this may be regarded as anthropomorphism, but the emphasis is placed on their lack of human reaction on their behalf, on the fact that they are not involved in the interactions, loaded with various interests and emotions, around them. A typical sentence about the lack of any change reads: "Meanwhile nothing changed in the life of the lime trees." (134) And another one about tree things: "Both lime trees were still alive, moreover they had grown bigger." (132) Living and growing, that is what trees do, whatever human fuss is going on around them. My third quotation will be a bit more complicated: "Both lime trees quietly enjoyed their income." (132-133) What is a quiet enjoyment like? I suppose it must be a rather passive, contemplative joy, something based on finding harmony with the world. Is it what the narrator thinks of tree life? Maybe. However, "enjoying income" is a legal term, in which pleasure does not play a role. I can enjoy an income even without having any delight in it. In this interpretation the sentence is not anthropomorphism, but a precise description of a legal situation-except for the implication of quietness.

And from this viewpoint, from that of the rights of the trees, the short story is quite provocative. Through a plot in which two trees acquire or are regarded to have acquired rights, which the society of the time granted only to humans, the short story experiments with environmental rights. Can living creatures that are not humans seriously have rights, or is this nonsense? Can a man be taken seriously who places on himself a moral judgement for cutting down a tree from the universal and sublime viewpoint of nature? If two trees can be regarded as persons with individual right, why not all trees? And these questions from this story from 1900 are quite familiar for ecocritics, who find it surprisingly hard to convince people that everyday acts, regarded as completely insignificant in human society, have immense ethical importance from a global environmental viewpoint.

A couple of years ago a book on the future of ecocriticism took a 1930 event as a starting symbol for environmental protection, when Kemal Atatürk refused permission to cut some branches off a plane tree that was damaging a mansion, therefore the mansion was moved. In the picture printed in that book we can see that an enormous quantity of wood was used to build the rails on which the mansion could "walk" (Oppermann et al. 2011, vi). Many other trees died to save branches of one particular tree that was regarded precious for particular reasons by human society. Similarly, Mikszáth told a story of two particular trees, but a story that also provokes generalisation. Under special circumstances human society grants some rights to two lime trees. The human protagonist applies a universal viewpoint and thinks a tree has the right to live. The story provokes the question if every tree should be granted certain rights.

\begin{tabular}{|l|llll|}
\hline & Journal : Small-ext 11059 & Dispatch : & $\mathbf{2 1 - 6 - 2 0 1 7}$ & Pages : 13 \\
Article No. : $\mathbf{4 0 1}$ & $\square \quad$ LE & $\square$ & TYPESET \\
& MS Code : NEOH_Ecocriticism_8_Hajdu & $\square \quad$ CP & $\square$ & DISK \\
\hline
\end{tabular}




\section{References}

477

478

479

480

481

482

483

484

485

486

487

488

489

490

491

492

493

494

495

496

497

498

499

500

501

502

503

504

505

506
A Pallas nagy lexikona. (1894-1897). 18 vols. Budapest: Pallas. http://mek.oszk.hu/00000/00060/html. Accessed August 24, 2016.

Aristotle. (1927). Poetics (Trans: Rhys, R. W.). In Aristotle, Poetics; "Longinus," On the sublime; Demetrius, On style (pp. 5-118). London: Heinemann.

Estok, S. (2016). Ecomedia and ecophobia. Neohelicon, 43, 127-145.

Freud, S. (1900). Traumdeutung. Leipzig/Wien: Franz Deuticke.

Hajdu, P. (2012). Tudás és elbeszélés. A Mikszáth-kispróza rejtelmei. Budapest: Argumentum.

Kráhl, V. (1941). Mikszáth, a jogász. Budapest: Vajna és Bokor.

Mikszáth, K. (1900). A kompossessor fák. Vasárnapi Ujság, 47(51-52), 846-849 and 866-868.

Mikszáth, K. (1901). A kompossessor fák. In K. Mikszáth, Öreg szekér fakó hám (pp. 1-33). Budapest: Légrády.

Mikszáth, K. (2015). A kompossessor fák. In Mikszáth Kálmán összes müvei [The complete works of Kálmán Mikszáth] Vol. 43 (Ed. P. Hajdu) (pp. 129-146). Budapest: Argumentum.

Mogg, K. (2009). The day of the claw: A synoptic account of Alfred Hitchcock's The Birds. Senses of Cinema, 51. http://sensesofcinema.com/2009/towards-an-ecology-of-cinema/Hitchcock-birdssynopticaccount. Accessed August 10, 2016.

O'Connor, F. (1953). The lonely voice: A study in the short story. Cleveland: The World Publishing Company.

Oppermann, S., Özdağ, U., Özkan, N., \& Slovic, S. (2011). The future of ecocriticism: New horizons. Cambridge: Cambridge Scholars.

Otto, R. (1917). Das Heilige. Breslau: Trewendt \& Granier.

Paterson, D. (2009). Rain. London: Faber and Faber.

Pikulik, L. (1979). Romantik als Ungenügen an der Normalität. Frankfurt am Main: Suhrkamp.

Pratt, M. L. (1981). The short story: The long and the short of it. Poetics, 10, 175-194.

Roscher, W. H. (1886-1890). Ausführliches Lexikon der griechischen und römischen Mythologie. Leipzig: Teubner.

Todorov, T. (1975). The fantastic (Trans: Howard, R.). Ithaca, NY: Cornell UP.

Wald, P. (2013). Botanophobia: Fear of plants in the atomic age. Japanese Journal of American Studies, 24, 7-27.

\begin{tabular}{|l|lllll|}
\hline & Journal : Small-ext 11059 & Dispatch : & $\mathbf{2 1 - 6 - 2 0 1 7}$ & Pages : 13 \\
Article No. $: 401$ & $\square \quad$ LE & $\square$ & TYPESET \\
& MS Code : NEOH_Ecocriticism_8_Hajdu & $\square$ & CP & $\square$ & DISK \\
\hline
\end{tabular}

